\title{
REVITALIZATION OF BADAN PENASIHATAN, PEMBINAAN DAN PELESTARIAN PERKAWINAN (BP4) IN PERFORMING COURT-ANNEXED MEDIATION FOR MARITAL DISPUTES IN RELIGIOUS COURT IN D.I.YOGYAKARTA*
}

\author{
Haniah Ilhami** \\ Department of Islamic Law, Faculty of Law, Universitas Gadjah Mada, Yogyakarta \\ Jalan Sosio Justicia No 1 Bulaksumur, Sleman, D.I. Yogyakarta 55281
}

\begin{abstract}
This research identify the revitalization of Badan Penasihatan, Pembinaan dan Pelestarian Perkawinan (BP4) in performing Court-annexed mediation for Marital Dispute in Religious Court in D.I. Yogyakarta and founds institutional transformations including the Legal Basis, Institutional Form, Institutional Relation with Ministry of Religious Affair, Employement/Management and Financial Provisions. In performing Court-annexed mediation, BP4 in D.I. Yogyakarta has been cooperating with 2 (two) Religious Courts, both in Wonosari and Yogyakarta in the placement of certified mediator from BP4 and their financing. All mediation process are bound by Regulation of The Supreme Court No. 1 year 2016 concerning Procedures of Court-annexed Mediation.
\end{abstract}

Keywords: BP4, court-annexed mediation, marital dispute.

\section{Intisari}

Penelitian ini mengkaji revitalisasi Badan Penasihatan, Pembinaan dan Pelestarian Perkawinan (BP4) dalam melaksanakan fungsi mediasi untuk sengketa perkawinan di Pengadilan Agama D.I. Yogyakarta. Penelitian menemukan perubahan kelembagaan BP4 dalam Dasar Hukum, bentuk lembaga, hubungan kelembagaan dengan Kementerian Agama, Ketentuan Kepegawaian/Kepengurusan dan Pendanaan. Untuk melaksanakan mediasi di Pengadilan Agama, BP4 D.I. Yogyakarta melakukan kerjasama dengan Pengadilan Agama Yogyakarta dan Wonosari dalam penempatan Mediator Bersertifikat dari Bp4 dan pendanaan untuk mereka. Seluruh proses mediasi terikat pada Peraturan Mahkamah Agung No. 1 tahun 2016 tentang Prosedur Mediasi di Pengadilan.

Kata Kunci: BP4, mediasi pengadilan, sengketa perkawinan.

\section{Pokok Muatan}

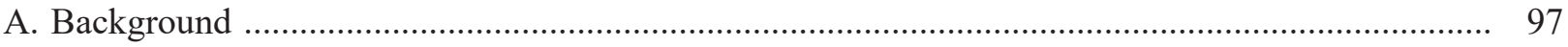

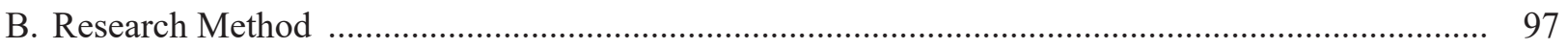

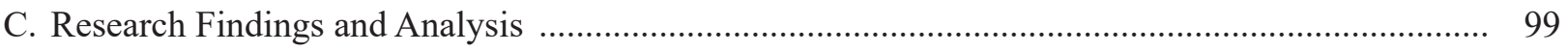

1. Intitutional Tranformation of BP4 before and after The 14th BP4 National Conference in 200999

2. Application of Supreme Court Regulation No. 1 year 2016 concerning Procedures of Court-annexed Mediation for BP4 in performing court-annexed mediation in Religious Court 101

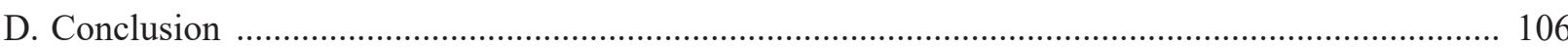




\section{A. Background}

Founded in 1962, Badan Penasihatan, Pembinaan dan Pelestarian Perkawinan (hereinafter referred to as BP4), an institution of Advisory, Development and Preservation of Marriage, was intended as a marriage consulting agency in Indonesia which professionally provide assistance of solving internal family dispute between a husband and wife. Since the establishment of BP4, Kantor Urusan Agama or Marriage Registration Office (hereinafter referred to as KUA) is no longer allowed to directly accept the registration of divorce. All marital disputes, including the divorce should firstly report to BP4 for consultation and professional advice which has implications for the delays in registration and announcement of divorce ${ }^{1}$ The consultation process was intended to provide opportunities for couples to reconsider their plans of divorce, thus helped the government in reducing the rate of divorce in Indonesia. At that time, in some regions in Indonesia, BP4 has successfully managed to reduce the number of divorces. ${ }^{2}$ However, this condition has been changed. Statistics nowadays show that the divorce rate is increasing significantly. In fact, divorce cases have always dominated in the statistics of types of cases received by the Religious Courts in Indonesia. ${ }^{3}$

In order to improve the existance of BP4, in 2009, BP4 started to revitalize itself, both institutionally and functionally. Functionally, the revitalization process was conducted through The 14th BP4 National Conference in 2009, which resulted in decisions about strategic transformation of BP4, starting from institutional tranformation to the expansion of the functions and authority of the institution. Institutionally, BP4 which was originally a part of the organization of the Ministry of Religious Affairs, under the Directorate General of Islamic Guidance Society, then through the Decision of the BP4 National Conference in 2009, became an independent and professional institution engaged in social and religious society and as partner of the Ministry of Religious Affairs as well ${ }^{4}$. As an independent agency, BP4 expands its functionality where BP4 not only as a counseling agency, but also have more comprehensive duties, including to provide mediation assistance to the litigants in the Religious Courts ${ }^{5}$ At the same time, the Religious Courts already has its own rules of the mediation process through Regulation of Supreme Court Regulation No. 1 year 2016 concerning Procedures of Court-Annexed Mediation.

Based on those conditions, the legal problems in this research are the institutional tranformation of BP4, the application of Supreme Court Regulation No. 1 year 2016 concerning Procedures of Courtannexed Mediation for BP4 in performing courtannexed mediation in Religious Court, and implementation of Court-annexed Mediation for Marital Dispute at Religious Court in D.I. Yogyakarta.

\section{B. Research Method}

This research combines both of normative legal research (literature research) and empirical legal research (field research). Under these conditions, this research examines the revitalization of BP4 after The 14th BP4 National Conference in 2009, in performing Court-annexed mediation for Marital Dispute at Religious Court in D.I. Yogyakarta.

\section{Literature Research}

Literature research is conducted in two (2) phases, before and after the field research.

\footnotetext{
Regarding Law No. 22 year 1946, KUA has the authority to receive, solve, and register the Divorde. untuk menerima, menyelesaikan, dan melakukan pendaftaran atas perkara talak. This competence the removed through Law No. 1 year 1974 and Law No. 7 year 1989.

Daniel S. Lev, 1986, Peradilan Agama Islam di Indonesia: Suatu Studi tentang Landasan Politik Lembaga-Lembaga Hukum, Intermasa, Jakarta, p. 192

Pengadilan Agama Surabaya, "Statistika Perkara selama tahun 2015 pada Pengadilan Agama seluruh Indonesia", http://perkaranet.ptasurabaya.go.id/v1/action/fwJenisPerkara.php?c pta=ms.pta.all, accessed 20 Januari 2016.

Art. 3 Article of Association of BP4 year 2009

Art. 6 Article of Associatio of BP4 year 2009.
} 
Literature research that is conducted prior to the field research aims to provide the basic concepts and guides for researcher to carry out the next stage of research. Literature research conducted after the field research aims to analyse the results from the respondents and interviewees in accordance with the principles of Islamic inheritance law. In more detail, the literature research that has been done is as follows: a) Research tools. This literature research uses general secondary data includiny official documents, the results of previous research, and other library materials; b) Research material. Literature research consists of 3 (three) materials, which are the primary legal materials, secondary legal materials and tertiary legal materials, with systematics; primary legal materials are any regulations closely related to the study, includiny, laws and regulations: a) Law No. 22 Year 1946 concerning Registration of Marriage, Divorce and Reconciliation b) Law No. 1 year 1974 concerning Marriage; c) Law No. 7 year 1989 concerning Religious Courts as last amended by Law No. 50 year 2009 concerning the Third Amendment of Law No. 7 year 1989 concerning Religious Courts; d) Law No. 20 year 1997 concerning Non-Tax State revenue, e) Law No. 30 year 1999 concerning Arbitration and Alternative Dispute Resolutions, e) Presidential Instruction No. 1 year 1991 concerning the Compilation of Islamic Law; f) Government Regulation No.10 year 1983 concerning Permit of Marriage and Divorce for Civil Servants as amanded by Government Regulation No.45 year 1990 concerning Amandement of Government Regulation; g) Government Regulation No. 47 year 2004 concerning Rates and Types of Non-Tax State revenue in Ministry of Religious Affairs as amanded by Government Regulation No. 48 year 2014; h) Presidential Regulation No. 145 year 2015 concerning Eight Amandement of Presidential Decree No. 103 year 2001 concerning Status, Tasks, Function Authority, Organizational Structure and Work Procedures of Non Departmental Government Institutions; i) Minister of Religious Affairs Regulation No. 24 year 2014 concerning
Non-Tax State revenue on Cost of Marriage and Reconciliation held outside the KUA; j) Minister of Interior Regulation No. 32 year 2011 concerning Guidance of Government Grant and Social Asssistance sourced from Local Government Budget as amanded by Minister of Interior Regulation No. 14 year 2014.

Decision of the AdministrativeOfficer,Decree, Circular Letter, and other binding legal materials, includes: a) Decree of Minister of Religious Affairs No. 30 year 1977 concerning Recognision of BP4; b) Decree of Minister of Law and Human Rights No. AHU-100.AH.01.06 year 2010 concerning Validation of Association; c) Decree of Governor of DKI Jakarta No. 308 year 2016 concerning Grants, Social Assistance and Financial Aid in the Form of Money for Individuals, Families, Communities, Society, Community Organizations and Political Parties in budget year of 2016; d) Supreme Court Regulation No. 1 year 2016 concerning Procedures of Court-annexed Mediation; e) Decree of Supreme Court No. 062/KMA/ SK/IV/2011 concerning Accreditation to BP4 as Operator of Mediation Training; f) Memorandum of Understanding between Directorate General for Religious Courts (Badilag) with The Central BP4 No. 0777/Dj.A/ HM.01.1/03/2016 - No. 030/7-P/BP4/III/2016; g) Memorandum of Understanding between Religious Court of Yogyarakta and BP4 Yogyakarta No. W.12. A1/987/HK.05/IV/2014-Nomor 04/D.12/BP4/ IV/2014 concerning Implementation of mediation; h) Decree of The 14th BP4 National Conference in 2009 year 260/2-P/BP4/VIII/2014 concerning Article of Association of BP4 in year 2014.

Secondary legal materials, are materials that explain the primary legal material,includiny: 1) The books that discuss BP4 in general and Courtannexed mediation in particular; 2) Other results of legal research and opinion of legal experts to discuss related issues; 3) Magazines, journals and newspaper articles related to the related problem, both nationally and internationally; 4) The writings contained in the internet sites related to the problem. Tertiary legal materials, any legal materials that 
give instructions and explanations of the primary and secondary legal materials, which include: 1) Legal Dictionary; 2) Indonesian Dictionary; 3) Encyclopedia.

\section{Analysis Method}

Research was done by finding, selecting, analising, collecting, and comparing all legal materials related to the research problem, to make the conclusions related to the problem. The research uses a qualitative analysis method with data that are collected, selected, and studied as a whole so it can give a comprehensive description.

\section{Field Research}

The field research was conducted through the Focus Group Discussion by inviting religious court judges as expert speakers. The speakers who participated in the discussion were 1 (one) Judge from each Religious Courts in Special Region of Yogyakarta, includiny the Religious Court in Bantul, Religious Court in Wonosari, Yogyakarta, Wates, and Sleman. In addition, this research includes a Chairman of BP4 in D.I. Yogyakarta, 1 (one) speaker as representative of each Ministry of Religious Affairs and Office of Religious Affair. From the results of field research, the data analysis was done by processing and analysing directly using the descriptive qualitative method. The process is conducted into a broad description, the it conclude the results comprehensively.

\section{Research Findings and Analysis \\ 1. Intitutional Tranformation of BP4 before and after The 14th BP4 National Con- ference in 2009}

The process of revitalization in order to strengthen the institution of BP4 conducted through several internal tranformation. The most fundamental point of institutional revitalization was through The 14th BP4 National Conference in 2009. In this National Conference, BP4 declares itself as an independent institution after many years BP4 declares itself as an independent institution where prior to the conference was a part of the Ministry of Religious Affairs. This significant transformation led to another development in the institutional form, duties, and functions of BP4. Compared with the prior position, the institutional development of BP4 after The 14th BP4 National Conference in 2009 can be summarized as follows:

Table 1.

Intitutional Tranformation of BP4 before and after The 14th BP4 National Conference in 2009

\begin{tabular}{ll}
\hline Before The 14th BP4 National Conference & $\begin{array}{l}\text { After The 14th BP4 } \\
\text { National Conference }\end{array}$
\end{tabular}

Institution Name

Legal Basis

Form
Badan Penasehat

Perkawinan dan

Penyelesaian Perceraian

Badan Penasehat Perkawinan, Perselisihan, dan Perceraian

Minister of Religious Decree No. 85 year 1961

Supporting Agency under Departement of Religious Affairs
Badan Penasihatan, Pembinaan, dan Pelestarian Perkawinan

Decree of The 14th BP4 National Conference No. 26/2-P/BP4/VI/ 2009 concerning Article of Association of BP4

Community Organization with Legal Entity of Association 


\author{
Institutional \\ Relation with \\ Ministry of \\ Religious \\ Affair \\ Employement/ \\ Management \\ Provisions \\ Part of the organization of the Ministry of Religious \\ Affairs, under the Directorate General of Islamic \\ Guidance Society \\ Attached to Stuctural Position in Ministry of Religious \\ Affairs
}

Financial

Provisions

Funds from a Non-tax State Revenue derived from Cost of Marriage, Talak, and Reconciliation
As partner of Ministry of

Religious Affairs

Anyone who is eligible and proposed by the Council BP4, may become Management Board

Funds obtained from various sources

Source : Processed by Author, 2016.

The institutional transformation above also has a significant implication to the function and duties of BP4 itself. While previously BP4 was only a consultation agency for marital dispute, through this National Conference they expand to more comprehensive duties such as: ${ }^{6}$

1. Providing guidance, advice and information concerning marriage, divorce, and reconciliation to the community, both individuals and groups;

2. Providing guidance on legislation relating to the family;

3. Providing mediation assistance to the litigants in the religious court.

4. Providing advocacy assistance in overcoming the problem of marriage, family and domestic disputes in religious courts;

5. Lower the the rate of divorce, unresponsible polygamy, underage and unregistered marriage

6. Work with agencies, institutions and organizations that have similar objective both inside and outside Indonesia;

7. Publish and disseminate marriage and family magazines, books, brochures and electronic media when necessary;

8. Holding pre-marital courses, discussions, seminars and similar activities-relating to marriage and family

9. Holding a family education for enhancing the appreciation and practice of the values of faith, devotion and good moral in order to establich harmonious family

10. Participate actively participate in any cross-sectoral activities to establish a harmonic family

11. Improving the economic empowerment of the family;

12. Any other activities related to the interests of the organization as well as to the happiness and well-being of the family.

This research focuses on the implementation of the mediation function in court, or also known as court-annexed mediation, as stipulated above. The addition of these functions will put BP4 an institutions that is actively involved in the trial process through mediation stage. On the other hand, the Supreme Court has been regulated in detail the procedures of court-annexed mediation which will bind all parties, including BP4 as the new party that will be actively involved in this process. It requires in-depth study of how this involvement is implemented in accordance with the internal regulations in Religious Courts. 


\section{Application of Supreme Court Regulation} No. 1 year 2016 concerning Procedures of Court-annexed Mediation for BP4 in performing court-annexed mediation in Religious Court

As a new institution that has an authority in performing court-annexed mediation, BP4 bound by the rules of court-annexed mediation under the Supreme Court Regulation No. 1 year 2016 concerning Procedures of Court-annexed Mediation (hereinafter reffered to as Supreme Court Regulation No. 1/2016). Supreme Court Regulation No. 1/2016 which regulates the whole procedures of court-annexed mediation and all its requirements. Related to the the function of mediation by BP4, the implementation Supreme Court Regulation No. 1/2016 explains in these following conditions:

a. BP4's position as a mediator in the Religious Court

Supreme Court Regulation No. 1/2016 classifies 2 (two) types of court-annexed mediation based on the type of mediators, which are: ${ }^{7}$

1. Internal Mediator Internal mediator is a Judge and Staff of Court.

2. External mediator External mediators are any other parties outside the court who have a Mediator Certificate. ${ }^{8}$ Mediator Certificate means a document stating that someone has passed a mediaton training isssued by Supreme Court, or other institution accredited to the Supreme Court. Related with the position of BP4, any member will be allowed exercising the mediator function specifically in Religious Court only if they possess the Mediator Certificate after participating in mediation training.

\section{b. Provisions of types of cases mediated by BP4}

Supreme Court Regulation No. 1 year 2016 regulates that all civil disputes submitted to the Court, with some exception, must first be settled amicably with the facilitation of a mediator. ${ }^{9}$ Furthermore, referring to authority of BP4 in marital dispute, there are two (2) cases exempt from types of cases mediated by $\mathrm{BP} 4$, which are: ${ }^{10}$

1. Disputes regarding Prevention, Rejection, Annulment, and Validation of Marriage.

2. Dispute filed to the Court after the attempted settlement out of court through mediation with the assistance of a Certified Mediator registered at the local court, but declared unsuccessful based on a statement signed by the Parties and the Certified Mediator.

This exclusion has a strong correlation with both BP4 function as a mediator for Islamic family dispute and the implementation of Principle of Simple, Fast, and Low Cost in the Religious Court. Based on this exception, if the case has been through the process of mediation conducted by a Certified Mediator before the case is brought to trial, and the mediation process fails to reconcile the parties, at the time of the case submitted to the Court, no longer need to go through another court-annexed mediation. Certified Mediator of BP4 can take advantage of this provision by seeking mediation for islamic family disputes Islam before the dispute is 
submitted to the Religious Courts. When this is done, it will speed up proceedings for the because it is no longer need to go through the process of court-annexed mediation in the Religious Court.

c. The provisions of the Mediator's Fee

Supreme Court Regulation No. 1/2016 classifies the provisions mediator's fee into 2 (two) conditions:

1. Mediation by internal mediator The use of internal mediator is free of charge

2. Mediation by external mediator External mediator's fee will be jointly borne by the parties or as otherwise mutually agreed by the parties. As an external mediator, any certified mediator from BP4 will get a fee in accodance with this provision

d. Provision on The Venue Of Mediation

Supreme Court Regulation No. 1/2016 classifies the provisions venue of mediaton into 2 (two) conditions: ${ }^{11}$

1. Mediation by internal mediator Mediation with internal mediator should be conducted in the court which receive the case

2. Mediation by external mediator Mediation may be conducted in other place and any costs associated there will be borne by the parties as mutually agreed. Based on this provision, any mediation conducted by certified mediator from BP4 may be held in any place, both inside or outside the court.

\section{e. Provision on the Duration of Mediation Process \\ Referring to Supreme Court Regulation} No. $1 / 2016$, the mediation process conducted both by internal or external mediator, including certified mediator from BP4, should last for 30 (thirty) working days. On the grounds of specific reasons, the timeframe of mediation process can be extended up to a period of not longer than other 20 (twenty) working days.

\section{Implementation of Court-annexed Media-} tion for Marital Dispute at Religious Court in D.I. Yogyakarta.

In performing court-annexed mediation for marital dispute, BP4 cooperated actively with Supreme Court in order to enhance the capabilities of its member to be able to perform the mediation in Religious Court. BP4 has been accredited as Operator Mediation Training by Supreme Court through The Decree of The Head of Supreme Court $^{12}$. By this accreditation, BP4 are now able to organize the mediation training to prepare their own member in becoming a Certified Mediator.

Cooperation between BP4 and the Supreme Court also reinforced through a Memorandum of Understanding between the Directorate General for Religious Courts (Badilag) with The Central BP4 ${ }^{13}$. Through this Memorandum of Understanding, both institutions agreed to develop the capacity of human resources of BP4's members in performing courtannexed mediation for islamic marital disputes in Religious Court. In order to achieve these objectives, the Directorate General for Religious Courts (Badilag) and The Central BP4 have also agreed that :

1. The Central BP4 will provide mediation training and issue the Mediator Certificate

Look Art. 11 (1) and (3) Supreme Court Regulation No. 1 year 2016 concerning Procedures of Court-annexed Mediation.

Decree of Supreme Court No. 062/KMA/ SK/IV/2011 concerning Accreditation to BP4 as Operator of Mediation Training.

Memorandum of Understanding between Directorate General for Religious Courts (Badilag) with The Central BP4 No. 0777/Dj.A/ HM.01.1/03/2016 - No. 030/7-P/BP4/III/2016. 
2. Directorate General for Religious Courts (Badilag) will help the placement of a certified mediator in the Religious Court, and

3. Directorate General for Religious Courts (Badilag) and BP4 will jointly undertake monitoring and provide guidance on a certified mediator from BP4

In D.I. Yogyakarta in particular, those cooperations was further strengthened at the level of district/city through another more specific Memorandum of Understanding between BP4 and Religious Courts in some districts. There are two districts that have done similar Memorandum of Understanding, City of Yogyakarta and District of Wonosari, while others will soon conduct the similar cooperation in order to reinforce to competence of BP4 as mediator in performing court-annexed mediation in Religious Court.

Position of BP4 D.I. Yogyakarta in performing court-annexed mediation has been recognized through Memorandum of Understanding, nevertheless its revitalization proceeded very slow. The main problem in this condition is the existence of financial and human resource difficulties ${ }^{14}$ BP4 D.I. Yogyakarta has been trying to find a solution to this problems through cooperation with various parties, including the Local Government and Local Religious Court, in the following forms:

\section{a. Cooperation in the placement of certified mediator from BP4}

In the beginning of the revitalization, many question the capability of BP4 member in performing court-annexed mediation. Referring to Supreme Court Regulation, becoming an in court-mediator needs a Mediator Certificate after passing the specific formal training organized by accredited institution, while in practice, there are still many internal mediators, including judges and staff of court, that has not been able to meet this requirement due to various reasons. Considering that the certificate will only be issued after a specific mediation training that contains of mostly legal materials, it is doubtful whether BP4 members, which coming from non-legal backgrounds, will be able to meet this qualification.

However, BP4 in D.I. Yogyakarta responds those questions through positive action succesfully. The Board of BP4 in D.I. Yogyakarta was very responsive to deal with the revitalization. Right after The 14th BP4 National Conference in 2009, BP4 in D.I. Yogyakarta immediately assign some members to attend and completed the training of mediators and get their Mediator Certificate. Until this research is conducted, there are 5 (five) members of BP4 who received a Mediator Certificate, making them become eligible to perform court-annexed mediation in Religious Court ${ }^{15}$ To continue empowering those Certified Mediator, BP4 in D.I. Yogyakarta cooperated with 2 (two) Religious Court in D.I. Yogyakarta which are Religious Court of City of Yogyakarta and Religious Court of Wonosari, through Memorandum of Understanding concerning the placement of certified mediator from BP4 in each Religious Courts. In this Memorandum of Understanding, both parties agreed to assign all certified mediator from BP4 in both courts. The Memorandum of Understanding between BP4 City of Yogyakarta and Religious Court in Yogyakarta, for example, had arranged that all certified mediators of BP4 will get a schedule of mediation

Opinion from Mr. H. Nur Ahmad Ghojali, M.A. as Representative of Mistry of Religious Affairs in D.I. Yogyakarta in Focus Group Discussion held in Yogyakarta, 9 September 2016.

15 Opinion from Mr. H. Nur Ahmad Ghojali, M.A. as Representative of Ministry of Religious Affairs in D.I. Yogyakarta in Focus Group Discussion held in Yogyakarta, 9 September 2016.

16 Memorandum of Understanding between Religious Court of Yogyarakta and BP4 Yogyakarta No. W.12.A1/987/HK.05/IV/2014-Nomor 04/D.12/BP4/IV/2014 concerning Implementation of mediation. 
in the Religious Court every Monday to Thursday ${ }^{16}$. Through this cooperation, BP4 in D.I. Yogyakarta has managed to revitalize its own human resource.

\section{b. Cooperation in Funding The Certified Mediators}

Formally, BP4 is eligible to receive funding from various sources. However, in D.I. Yogyakarta, it is very difficult to do so. As a newly transformed institution, BP4 focused more on institutional development and human resources development rather then rising fund.. For the solution, some local governments took the initiative to help BP4 in their region through the provision of Government Grants sourced from Regional Government Budget ${ }^{17}$. For example, the Government of Bantul regulates the Decree of the Regent of Bantul No. 114 year 2012 concerning The List of Recipients and Amount of Grant from Government of Bantul, which determine the amount of the Goverment Grant for BP4 in Bantul which is equal to $\mathrm{Rp} \cdot 15.105 .000$, - derived from Regional Government Budget of Bantul. By this Grants, the Government of Bantul helps the daily operating costs of BP4.

In Religious Court, certified mediator from BP4 also has to deal with similar difficulties. Referring to Supreme Court Regulation No. 1 year 2016 concerning Procedures of Court-annexed Mediation (hereinafter referred to as Supreme Court Regulation No. 1/2016), the external mediator's fee will be jointly borne by the parties or as otherwise mutually agreed by the parties. This fee is excluded from the Courts Charged that also should be paid by the parties. This has led to the reluctance of the parties to use the certified mediators from BP4 because they have to do a doublepayment for their case, and prefer an internal mediator from inside the court which is free of charge. To anticipate this condition, the Religious Court initiate to cover the mediator's fee . For example, the Head of Religious Court in Wonosari prepared an internal budget to give the certified mediators from BP4 equal to Rp. 50.000,- for every case mediated. These initiatives helped certified mediator from BP4 as well as encouraging people to use the services of a mediator from BP4 in resolving their disputes since they do not have to pay an extra fee for mediators.

Based on 2 (two) cooperations between BP4, Religious Court, and District Government as mentioned above, this research finds that the difficulties in the revitalization of BP4, specifically in D.I. Yogyakarta, have found some solutions to improve the performance of certified mediators from BP4 to perform courtannexed mediation in Religious Court. This condition is also supported by the positive response from judges in each Religious Courts. This research finds that judges of Religious Court from all over the province of D.I. Yogyakarta gave their positive responds for the presence of certified mediators from BP4 in their office. This positive response was given by these following reasons:

\section{Certified Mediator from BP4 provides substantial assistance to support Judges in Religious Court}

Judges in Religous Court have many responsibilities, from litigation to administrative tasks, conducting the trial, mediating both parties, and preparing Court's Decision. As a part of their responsibility, the obligation to follow the procedure of dispute settlement through mediation as regulated in Supreme Court 
Regulation No. 1/2016 gives them an extra task that complicates their main duty. When the judge was focused on completing the examination of the case, they often suddenly get a call for mediation, making it difficult for judges to concentrate on their own cases.

After the presence of certified mediators from BP4 in court, all judges admit that they had received significant assistance, hence they can focus on completing their cases and no longer disturbed by the obligation to conduct the mediation. In the other side, BP4 also finds that Memorandum of Understanding concerning their placement in court is very helpful for giving them the opportunity to be directly involved in real cases of Islamic family law and can expand their knowledge about islamic law in general. After seeing the positive impact for both BP4 and Religious Court, all judges encourages greater synergy between BP4 and Religious Courts in all district in D.I. Yogyakarta.

\section{Certified Mediator from BP4 Who Have in Depth Knowledge about Islamic Law When Compared with Other External Mediator}

As a mediator, BP4 have enough basic knowledge about the principle of Islamic family law which has a lot specifications than general law. Procedural law in Religious Court in particular, also has specific provisions that are not regulated in the General Civil procedure law, for example, the provision of appointment of Hakam. In religious Court, for the divorce filed based on the reason of syiqaq, it needs an additional step in trial, which is the judge may appoint a third party from the family of husband or wife, for being a hakam, to assist the judge finding an internal solution to defend marriage from divorce. This additional procedure is actually the implementation of basic principle in islamic marriage law, which sometimes lacks the understanding about Islamic law. While most of the member of BP4 have an Islamic educational background, this kind of specifications will be easily applied in the mediation process. Mediator from $\mathrm{BP} 4$ has a vision to always defend the marriage and prevent the divorce at any cost. When he being a mediator in marital dispute, mediator from BP4 always tryies their best efforts in finding a solution to make the husband and wife reunited and cancel their divorce.

In comparison, advocates for instance, also have the opportunity to become a Certified Mediator and perform court-annexed mediation. However, an advocate may not have enough knowledge to the principles of Islamic family law and it shows in the process of mediation. As mediators, usually they do not focus on defending the marriage by helping both husband and wife finding the best solutions, but instead focusing on the division of joint property and child custody. This is then distinguishes certified mediator from BP4 with a other external mediator.

3. The Increasing Bumber of Cases That Successfully Mediated By Bp4 Mediation in The Religious Court

This research finds, based on a quick evaluation by judges in Religous Courts in D.I. Yogyakarta on the implementation of the court- 
annexed mediation conducted by mediators from BP4, that mediation by certified mediator from BP4 particularly effective in resolving the marital dispute. In some cases assisted by a certified mediator from BP4, all parties were successfully reconciled without taking their cases into the trial. One of the factors that led to this success is their deep knowledge about basic legal principles of Islamic law as previously mentioned. Furthermore, it is also reinforced by their consistency in doing best efforts to encourage the parties at reaching their amicable settlement. Comparing to the same mediation conducted by a judge, judges in Religious Court in general only held onetime-mediation without any further assitance to help the couple finding their internal solutions. The number of cases that must be resolved in trial along with the deadlines of each cases is the reason why the judges do not have enough time to organize the sufficient mediation process through multiple stages of mediation. As a results, most cases failed to reach any agreement.

Different conditions will be found in the case mediated by mediators from BP4. Mediator from BP4 usually hold a multiple mediation for each case in order to get in-depth information from the parties to help them tracing and finding main issues in their dispute and seeking various alternatives of the best resolution at once. In each stages of mediation, all mediators from BP4 perform various approaches to encourge both husband and wife to directly participate in the mediation process so they can open a dialog, express their own opinion, and often they also give some religious advice about the consequences of divorce from the perspective of Islamic law. All of these efforts have succeeded in reconciling the couple since most marital disputes occur due to lack of communication between husband and wife. These conditions increase the success rate of courtannexed mediation in Religious Court in D.I. Yogyakarta, and as the result, all judges gave their full support for the involvement of a mediator from BP4 in performing court-annexed mediation for marital disputes.

\section{Conclusion}

Based on the research that has been done and funded by the Research and Development Center Faculty of Law, Gadjah Mada University, it can be concluded that: Firstly, the revitalization of BP4 start at The 14th BP4 National Conference in 2009 which institutionally transforms BP4 in institution name, legal basis, institutional form, institutional relation with Ministry of Religious Affair, provisions of employement/management, and financial provisions. Secondly, in performing court-annexed mediation for marital dispute in Religious Court in D.I. Yogyakarta, BP4 has cooperated with Religious Court in City of Yogyakarta and Religious Court in Wonosari through Memorandum of Understanding in form of cooperation in the placement of certified mediator from BP4 and cooperation in funding the certified mediators. Those cooperations supported by all Judges in Religious Court and increase a number of successfully mediated cases of marital dispute. 


\section{REFERENCES}

\section{A. Books}

Amidhan,H., 1977, BP4 Pertumbuhan dan Perkembangan, Badan PenasihatPerkawinan, Perselisihan dan Perceraian, Jakarta

Badan Penasihatan, Pembinaan dan Pelestarian Perkawinan (BP4), 2009, Anggaran Dasar BP4 tahun 2009, Badan Penasihatan, Pembinaan dan Pelestarian Perkawinan (BP4), Jakarta

Badan Penasihatan, Pembinaan dan Pelestarian Perkawinan (BP4), 2009, Pokok-pokok Kerja Badan Penasihatan, Pembinaan dan Pelestarian Perkawinan (BP4), Badan Penasihatan, Pembinaan dan Pelestarian Perkawinan (BP4), Jakarta.

Badan Penasihatan, Pembinaan dan Pelestarian Perkawinan (BP4), 2014, Anggaran Dasar BP4 tahun 2014, Badan Penasihatan, Pembinaan dan Pelestarian Perkawinan (BP4), Jakarta

Huberman, Matthew B. Miles \& A. Michael Huberman, 1992, Analisis Data Kualitatif, Universitas Indonesia Press, Jakarta.

Lev, Daniel S., 1986, Peradilan Agama Islam di Indonesia: Suatu Studi tentang Landasan Politik Lembaga-Lembaga Hukum, Intermasa, Jakarta.

Mahkamah Agung, 2013, Buku II Pedoman Teknis Administrasi dan Teknis Peradilan Agama, Mahkamah Agung, Jakarta.

Mardani, 2016, Hukum Keluarga Islam di Indonesia, Kencana, Jakarta.
Nasar, M. Fuad, 1996, H.S.M. Nasaruddin Latif Biografi dan Pemikiran, Gema Insani Press, Jakarta.

Usman, Rachmadi, 2003, Pilihan Penyelesaian Sengketa di Luar Pengadilan, Citra Aditya Bakti, Bandung.

\section{B. Internet}

Pengadilan Agama Surabaya, "Statistika Perkara selama tahun 2015 pada Pengadilan Agama seluruh Indonesia", http://perkaranet.ptasurabaya.go.id/v1/action/fwJenisPerkara. php?c_pta $=m s . p t a . a l l$, diakses tanggal 20 Januari 2016.

\section{Regulations}

Law Number 22 Year 1946 concerning Pendaftaran Nikah, Talak dan Rujuk.

Law Number 1 Year 1974 concerning Marriage (State Gazette of The Republic of Indonesia Year 1974 Number 1).

Law No. 7 year 1989 concerning Religious Courts ( State Gazette of The Republic of Indonesia Year 1989 Number 73, Supplement to State Gazette of The Republic of Indonesia Number 3316).

Memorandum of Understanding between Religious Court of Yogyarakta and BP4 Yogyakarta No. W.12.A1/987/HK.05/IV/2014-Nomor 04/D.12/BP4/IV/2014 concerning Implementation of Mediation. 